\title{
Digital reading groups: renewing the librarian image
}

Balling, Gitte; Skouvig, Laura; Henrichsen, Lise Alsted

Published in:

New Library World

DOI:

10.1108/03074800810846001

Publication date:

2008

Citation for published version (APA):

Balling, G., Skouvig, L., \& Henrichsen, L. A. (2008). Digital reading groups: renewing the librarian image. New Library World, 109(1/2). https://doi.org/10.1108/03074800810846001 


\title{
New Library World \\ Emerald Article: Digital reading groups: renewing the librarian image \\ Gitte Balling, Lise Alsted Henrichsen, Laura Skouvig
}

\author{
Article information: \\ To cite this document: Gitte Balling, Lise Alsted Henrichsen, Laura Skouvig, (2008), "Digital reading groups: renewing the \\ librarian image", New Library World, Vol. 109 Iss: 1 pp. 56 - 64 \\ Permanent link to this document: \\ http://dx.doi.org/10.1108/03074800810846001
}

Downloaded on: 20-11-2012

References: This document contains references to 17 other documents

To copy this document: permissions@emeraldinsight.com

This document has been downloaded 1090 times since 2008. *

\section{Users who downloaded this Article also downloaded: *}

Hui Chen, Miguel Baptista Nunes, Lihong Zhou, Guo Chao Peng, (2011),"Expanding the concept of requirements traceability: The role of electronic records management in gathering evidence of crucial communications and negotiations", Aslib Proceedings, Vol. 63 Iss: 2 pp. $168-187$ http://dx.doi.org/10.1108/00012531111135646

Charles Inskip, Andy MacFarlane, Pauline Rafferty, (2010),"Organising music for movies", Aslib Proceedings, Vol. 62 Iss: 4 pp. 489 - 501

http://dx.doi.org/10.1108/00012531011074726

Gao Jian-zhi, Zhao Yao, Ma He-ling, Sun Yuan-Xia, (2008),"Theoretical analysis on coordinated development of urban transport system", Kybernetes, Vol. 37 Iss: 9 pp. 1308 - 1314

http://dx.doi.org/10.1108/03684920810907599

Access to this document was granted through an Emerald subscription provided by DET INFORMATIONSVIDENSKABLIGE AKADEMI

\section{For Authors:}

If you would like to write for this, or any other Emerald publication, then please use our Emerald for Authors service. Information about how to choose which publication to write for and submission guidelines are available for all. Please visit www.emeraldinsight.com/authors for more information.

\section{About Emerald www.emeraldinsight.com}

With over forty years' experience, Emerald Group Publishing is a leading independent publisher of global research with impact in business, society, public policy and education. In total, Emerald publishes over 275 journals and more than 130 book series, as well as an extensive range of online products and services. Emerald is both COUNTER 3 and TRANSFER compliant. The organization is a partner of the Committee on Publication Ethics (COPE) and also works with Portico and the LOCKSS initiative for digital archive preservation. 


\section{NLW}

$109,1 / 2$

\section{6}

Received 6 July 2007 Reviewed 9 August 2007

\section{Digital reading groups: renewing the librarian image}

\author{
Gitte Balling, Lise Alsted Henrichsen and Laura Skouvig
} The Royal School of Library and Information Science, Copenhagen, Denmark

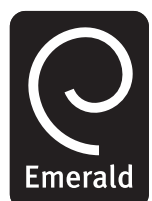

New Library World Vol. 109 No. $1 / 2,2008$ pp. $56-64$

(C) Emerald Group Publishing Limited 0307-4803

DOI $10.1108 / 03074800810846001$

\begin{abstract}
Purpose - The purpose of this article is to discuss the stereotype of the librarian and to point to the fact that changing the public view of the librarian requires more than just talking about it. Librarians themselves need to take action. A way to change the image of the librarian could be a new form for reading groups: digital reading groups initiated by libraries.

Design/methodology/approach - This article presents a Danish project concerning digital reading groups and the experiences made so far by the involved groups e.g. librarians and readers. The article introduces a historical view on the stereotyped librarian and uses a case study to illustrate the situation today.

Findings - The historical conditions that constitute the Danish librarian stereotype show a discrepancy between the role and function of the modern librarian and the way the librarian is seen in a wider public. The applied case study, concerning digital reading groups, shows that digital reading groups work both as a way for the librarian to communicate with the reader in a more dialogical fashion, as a way for the public library to test new promotion tools which point in direction of Web 2.0 and as a more flexible promotion offer to the busy reader. Consequently, the digital reading groups offer a model that can bridge the gap between the librarian stereotype, the librarian and the library user.

Originality/value - This article is based on experiences made in connection with a Danish literature promotion project where digital reading groups are launched for the first time. It shows how public libraries can use literature promotion on the internet, not only to reach new users, but also to change the librarian stereotype and upgrade the librarians in direction of Librarian 2.0.
\end{abstract}

Keywords Digital libraries, Reading, Librarians, Denmark

Paper type Research paper

\section{Introduction}

Discussions of librarians' image and its reception by a wider public are numerous and always followed by the statement: we have to market ourselves as information specialists, cultural workers, information architects and so forth. Still, librarians are to a large extent identified with dull spinsters whose prime concerns are meticulousness and organising books in a sphere of efficiency. This stereotype does, however, not correspond with the reality for many librarians in public libraries, businesses and organisations. Surprisingly enough, it seems to us, librarians themselves play an active role in the constant reconstruction of their stereotyped identity. In a changing society that demands new competences from librarians they often look backwards creating an image connected to an old librarian as a bogey instead of looking into their professional competences when (re)defining their identity.

This article is a reworked and extended version of a paper presented at the 15th BOBCATSSS symposium: Balling et al. (2007) 
This article discusses the new digital setting and, thus, how new demands from the users and society confront the librarians' identity and self-understanding. Our case study on digital reading groups shows how the well-known promotion of literature is changed into communication, dialogue and discussion with users. However, this dialogue is still based on the librarian's professionalism providing the librarian with a new form of authority. Also, the case study shows how the established concept of reading groups has changed in the digital setting.

The librarian stereotype has shown itself strong and has even survived the digital revolution in the public libraries. Despite new digital services, virtual libraries and a variety of different promotion features, the stereotyped image sticks to the librarian.

The main starting point is that the stereotyped librarian is both a weakness and strength for librarians in late modern society.

Much research has focused on the librarian stereotype. Our point of departure is an article written by Radford and Radford (2003) entitled "Librarians and party girls. cultural studies and the meaning of the librarian". They discuss the stereotyped librarian and they suggest that stereotypes operate only as a negative point of orientation. Radford and Radford (2003) base their study on the understanding of stereotypes offered by Hall (1997), stating that:

... [s]tereotypes get hold of the few "simple, vivid, memorable, easily grasped and widely recognized" characteristics about a person, reduce everything about the person to those traits, exaggerate and simplify them, and fix them without change or development to eternity (Hall, 1997, p. 258).

Understanding stereotypes only as something negative is, in our opinion, one-sided and does not leave much room for what we call the potential of the stereotype. Our view on stereotypes is inspired by the work of McGarthy et al. (2002). They encircle the positive effects of the stereotype by identifying three guiding principles:

(1) Stereotypes are aids to explanation. Meaning that stereotypes are widely accepted as an instantiation of the categorisation process; a cognitive process, which enables one to detect differences and similarities between groups. Easy recognisable characteristics of group members or social groups as a whole help to sort relevant information from irrelevant. One simply navigates in the world by categorising it.

(2) Stereotypes are energy-saving devices. Stereotypes reduce the information processing by offering a simplified meaning of big amounts of complex and detailed information. Through the stereotypes we accommodate a situation using little cognitive energy compared to the opposite situation, where we cannot just react on the basis of stereotypes but have to meet the "unknown" and spend energy accommodating the new impressions into our worldview. In other words, stereotypes are mental shortcuts to create meaning in daily life situations.

(3) Stereotypes are shared group beliefs. McGarthy et al. (2002) argue that stereotypes are created in a dialectic relation between individual group members, the group as a whole and individuals not belonging to the group. A diversion is not possible, e.g. saying that the librarian stereotype is created by others in order to ridicule the librarian profession. In fact the creation of the stereotype lies as much with the librarians themselves as with the outside

\section{Digital reading} groups 
NLW

$109,1 / 2$

\section{8}

world. Librarians create representations of themselves as group members on basis of issues such as labour unions, formal education and professional language. Representations also follow from the images that group members have of themselves due to the membership of the group. When librarians speak about professional subjects, saying "us" and "we", they give the impression that other librarians would think and do as them. Hereby, they feed the general image of the librarian in their own mind, and potentially in the minds of others outside the group of librarians.

Based on this basic definition, the authors discuss the construction of librarians' identity in Denmark by looking at how librarians throughout the twentieth century have (re)negotiated their identity. Another discussion theme is the fact that the self-identity of the librarians to a certain degree supports the stereotyped image. However, another point is how librarians could use the image constructively in order to overcome the stereotype. The last point is illustrated by the case study concerning digital reading groups in Denmark, where the librarian not only has to act as expert, counsellor and culture communicator, but also as a person in flesh and blood who is actually willing to exchange opinions with the individuals in the group. The digital reading groups challenge the role of the librarian, but also work in a way to renew both the image of the librarian and the communicative relationship between librarian and library user.

\section{Digital reading groups - a case study}

An example of an attempt at changing the librarian stereotype is as moderator in digital reading groups. Reading groups are not a new phenomenon. The phenomenon can be traced back as far as to the eighteenth century's saloons and coffee houses. However, the reading groups as we know them came forth at the same time as the modern public library in the beginning of the twentieth century - often as a tool to provide the underprivileged groups in society with access to knowledge (Lund, 2006). During the Second World War and the German occupation of Denmark, the reading group phenomenon expanded strongly causing a growth in literacy. New times and new habits in the 1960s meant a declining interest in reading groups. Today the reading group phenomenon experiences a revitalisation, which can be explained as a reaction to a more fragmented world and a more individual oriented society. In the reading groups, participants find a community where they can share thoughts, feelings, opinions, fears and joys in a like-minded group of people (Long, 2003). The growing focus on library users or book readers means that the libraries are very interested in reading groups - both as a way to reach book readers (and future library users) and as a way to gain knowledge about the reading habits of library users/book readers. Reading groups thus constitute both ends and means in literature promotion.

The Danish project is greatly inspired by Rachel van Riel who has created the leading British reader development organisation "Opening the Book" (van Riel and Thomas, 2007). "Opening the Book" focuses on a reader-centred literature promotion instead of the traditional book or author-centred literature promotion. Reader-centred reading groups focus on the experience of reading and are thus not concerned with a more academic approach to literature. They qualify the reader as expert no matter what previous knowledge the reader may have on the book in question. The aim is not just to bring by a better understanding of the book to each participant but also to share 
the reading experience in the group in order to illuminate the individual reading experience. This view of the reader/user is radically different from the way the authoritative librarian acted upon the user. Every tone or trace about the readers' lack of knowledge or competence concerning literature is gone.

Our case concerns digital reading groups, which means that the discussion takes place on the web. The participants in the reading groups are thus not located in the same room as is the case in traditional reading groups, but they comment on each other's opinions regarding the book under debate when and where it suits them. The only thing required is access to a computer where one can read and write comments. The reading groups have between 15 and 30 members and membership is free. One needs only to mail the moderator and fill out a couple of questions regarding age, gender, place of home and reading habits. The case "The Reading Club" involves 34 librarians and 270 readers spread over 23 different groups. The project is based in a literature promotion homepage shared by a majority of the Danish public libraries (www.litteraturssiden.dk, Fangel, 2000). The following experiences are collected in connection with an evaluation of the project conducted during spring 2007 (Balling, 2007). Both users and librarians have answered via mail qualitative questions regarding their experiences with discussing literature on the web. This method has been adopted to maintain the same form of communication, i.e. written communication, as used in "The Reading Club".

The interesting thing regarding the digital reading groups compared with traditional reading groups is the fact that the members are spread all over the country and participate in the discussion when and where it suits them. This provides on the one hand a great amount of freedom and flexibility for the members, but creates, on the other hand, less responsibility when it comes to activity in the group. In particular, flexibility is one thing which members point to when asked about the biggest advantage being in a digital reading group: "I like the fact that it is a free forum where one is not obliged to show up at a specific time and place. When ones time is limited, it's nice that I can 'go in my reading club' around midnight or while I watch television" (our translation). The lack of responsibility means that despite many members in the groups, only a minority takes part in the debate. This leads to the biggest disadvantage when asking both members and moderators: the dialogue is slow and sluggish. Most members point at the few participants in the discussion as an explanation hereof, but another circumstance that affects the dialogue, is the fact that it is written.

One or more librarians act as moderators in a reading group. The task for the moderators is to create a profile for the group and for herself, and to take responsibility for the group. Consequently, the librarian to a large extent stands up as an individual and not merely as a librarian. The theme, e.g. "Books on Food", "English Novelists", "World of Fantasy", "French Temptations", "Book Club of Forgotten Books", and the first four or five titles are chosen by the librarian in charge of the group, but future titles can be chosen by the group jointly. A book is scheduled for debate one month or more in advance where the participants can discuss themes closely connected to the book or more general themes. There are no rules regarding themes, but the librarian plays the role of moderator and thus opens the debate and gets it back on track in case of diversion. The role of the librarian is thus not only as provider of books or titles, but also as participant. The interesting aspect regarding this role is for the librarian to find

\section{Digital reading} groups 
NLW

$109,1 / 2$

60 a balance between the role as expert (providing the group with knowledge concerning the author, the period and the genre) and the role as an equal conversation partner.

The moderator's job is in many ways similar to the kind of literature promotion that the librarian is used to - the personal mediation of fiction to a user. However, the role as moderator also encompasses challenges when it comes to a new communication form, a new media and more personal promotion praxis. The unique thing about "The Reading Club" in contrast to other virtual literary discussion forums, is the fact that the moderator is a librarian who has taken on the role as a part of his or her promotion services. Other discussion forums are typically run by a layperson with interest in literature discussions, but without specific skills concerning literature. The professionalism of the moderators creates the frame in which the discussion takes place. The role as a moderator requires not only knowledge about literature and literary analysis, about new publications and forgotten classics, but also skills as literature mediator in relation to presenting and discussing topics in a way that secure participation from all members.

\section{New ways of communication - web 2.0}

However, the digital reading groups are not solely run by the moderators. Since the launch of the project in October 2006, the clubs have gradually established their own platform and style in extension of the wishes and needs of the members in the specific clubs. This way of letting the users influence the promotion in both form and content points in direction of the Web 2.0 phenomena. Web 2.0 is a shared description for "a movement towards a more dialogue based, personally and network oriented internet where everybody exchanges knowledge with everybody. Where the users themselves, children included, take turns as sender, receiver and judge of content" (our translation) (Klastrup, 2007, p. 55). Thus, the concept behind "The Reading Club" follows the tendencies that emerge all over the internet, and which also penetrates cultural promotion in general, where the users insist on having the opportunity to influence the promotion and the discussion.

The communication form used in the digital reading groups is best explained as a web log (blog). The moderator opens the debate, the members comment or launch their own contributions which can be commented on and so forth. The blog-genre is a quite new communication form on the internet. A blog is characterised by frequent updates and by short, informal and personally angled contributions (Klastrup, 2006). A blog has typically a distinct sender who writes about a subject that interests him or her. No matter what is commented or discussed on the blog, it is chosen by the sender from personal commitment. As a blogger one can choose to have a comment-function on one's blog so that others have the possibility to comment on the topics in discussion, but not all bloggers have made this choice. In this regard the digital reading clubs do not fit the blog-category one hundred percent in as much as there is a sender, the librarian, but the subject under discussion are defined by the club members in unison. Nevertheless, the dialogue takes place on the internet as a non-symmetric communication form, and some of the problems regarding the slow dialogue, as expressed by members and moderators, are due to the blog-form.

To "talk about books" on the internet, to "have a dialogue" is for most people synonymous with a discussion between two or more individuals being together in the same room, such as in a traditional reading group. This is the case because most people 
are unfamiliar with blogging as a way of communication. Most of the frustration connected to the slow dialogue derives from a failing fulfilment of expectations. The participants wants to discuss literature, they want the fast dialogue that characterises the verbal conservation. Such dialogue demands a live presence of the involved individuals on the internet, such as a chat. This would, however, mean compromising with the flexibility that most members emphasise as the main benefit with the digital reading groups. Alternatively, one needs to create a more dynamic dialogue in the blog and how to do that?

First of all, the communication form requires that members and moderators visit the blog frequently. Second, it requires a habit to discuss in writing. Short, quick stray thoughts in speech tone seem to have a favourable effect on the discussion. To most members and moderators "The Reading Club" is their first experience with blogging and it is obvious that it requires habit, both with regard to written dialogue and in relation to the blog-style that raises many questions:

- How often should one write?

- How long should one write?

- What tone of expression should be used?

- Why do the other members not answer my comments straight away?

As some of the moderators put it: "It is harder than we thought to express oneself briefly and precisely and at the same time create a pleasant and relaxed atmosphere" (our translation). An examination of the members' experiences shows that the moderator plays a very important role as link in this fragmented "conversation", a role that on the one hand is a continuation of the traditional library work and on the other hand is unfamiliar to many of the participants.

\section{New competences - Librarian 2.0}

Most of the members are satisfied with the way the moderators fill in their role. They see it as an advantage that a person with knowledge about literature acts as moderator. More members believe that the professional skills of the moderator secure a high level of quality both concerning the book selection and in the discussion.

As mentioned earlier, the role of moderator forces the librarian into a more dialogical form of communication than in the traditional librarian-user relation. As one moderator says:

I get a chance to discuss with the users in a different way than in the ordinary lending department. In the lending department you promote more than you discuss. On the web you discuss with others (our translation).

The moderator points at a significant difference in relation to traditional promotion in the library. The traditional promotion across the desk constitutes a clear sender-receiver relationship. The user comes to the librarian with a question or inquiry, which the librarian has an answer to. The librarian acts as an expert in relation to the user.

In "The Reading Club", the moderator acts as a member on equal terms with the other members. This is also seen in the fact that the members do not act differently in relation to the moderator than towards other members. The authority that follows the role as librarian in the relation with the user in the physical library dissolves on the

\section{Digital reading} groups

61 
NLW

$109,1 / 2$

62 web both as a result of the anonymity of the members, of the very personal way the librarian present himself or herself at the homepage and of the communication form. There is no desk on the web. The role as expert is reduced and the individual person's role behind the librarian is increased:

It is a role I had to get used to, the informal role where I to a larger degree have to use my personality. It is not that it is unnatural to me, it is just a new role (our translation).

Further, the role as moderator functions as upgrading of skills in relation to a future where digital promotion, also in shape of blogs and chat, will be a growing part of library services.

Were does this leave the stereotype? The stereotype was described as an explanation, as an energy-saving device and as a shared group belief, which altogether make the stereotype a navigation tool for librarians and library users. The librarian stereotype is so insistently well known and recognisable that it has a great potential. Furthermore, most members did underline the fact that a librarian leading the group as something that secures quality and professionalism. These qualifications are laid down in the spinster stereotype. Thus, in this case the stereotype functions as a hallmark securing quality.

On the other hand, the meeting between the librarian and the group members on the web in personal discussions on literary topics can act as a way to expand or even tear the stereotype down from within. The librarian acts in a more private and individual way that works against the concept of stereotypes. In the future literature promotion, librarianship and library services will, without any doubt, move in the direction of Web 2.0. Already, the expression Library 2.0 and Librarian 2.0 are used in LIS discourses. We would like to add to the concept of Librarian 2.0 a combination of professionalism such as the stereotype and a more personal appearance where conversation and dialogue with the library user is a central aspect.

\section{Conclusion}

This article has outlined the origin of the stereotype as a consequence of a power struggle at the beginning of the twentieth century providing the librarian with the status of being an expert. Eagerness to enforce professional but complex systems and social norms obviously made the librarians reinforce the stereotype themselves. Librarians partly worked to recreate and stabilise society, partly to meet the needs of the users. This ambiguity, along with the enforcement of the organisation systems and the strict social norms in the library, might explain the use of the adverbs strict, controlling and dull when describing the stereotype.

In the authors' view a historical dimension gives the possibility of qualifying arguments in our discussions today. We all know the stereotype of the spinster and we are aware that librarians desperately want to avoid this stereotype. However, in doing so, they reinforce the spinster. Using history we want to illustrate how history itself has turned into what Wiegand (1999) calls "a blind spot". Familiarity with the stereotype and its historical basis makes librarians define themselves in relation to what they see as the past librarian - not seeing what competences they actually have.

When it comes to the personal meeting between the individual librarian and the user the situation is a bit different. Since the 1960s the relation between librarians and library users has been characterised by a growing equality, but still the desk has in 
some way interfered with the dialogue, representing the social norms in the library. The organisation of digital reading groups sets new frames that allow the librarian to step forward as a person in flesh and blood, and thus transcend the profession and consequently the stereotype.

However, digital reading groups not only force the librarian to act in a more personal way, they also turn the roles of sender and receiver upside down making room for dialogue and for the members to play the role as experts in case they have a certain knowledge. The possibilities offered in Web 2.0 can be seen as a development tool where the librarian can practise new ways of communication and promotion.

In the future, we will see a growing demand for more user-centred library promotion that requires both personality and individuality, and also professional expertise from the librarian. However, we still need the stereotype to signal specialised knowledge and professionalism.

\section{References}

Balling, G. (2007), "Virtuelle læseklubber - på vej mod bibliotek 2.0" (in Danish), available at: www.db.dk/gb (accessed 10 September 2007).

Balling, G., Henrichsen, L.A. and Skouvig, L. (2007), "Marketing the profession: let the spinster do the job?", Marketing of Information Services. Proceedings of The 15th BOBCATSSS Symposium, 29-31 January, 2007, Prague, Czech Republic, pp. 55-66.

Fangel, G. (2000), Litteratursiden.dk (In Danish), available at: www.litteratursiden.dk/sw464.asp (accessed 6 July, 2007).

Hall, S. (1997), "The spectacle of the 'other", in Hall, S. (Ed.), Representation: Cultural Representations and Signifying Practices, Sage, London, pp. 223-79.

Klastrup, L. (2006), "Hvordan man skaber en genbesøgelig weblog" (in Danish), available at: www.kommunikationsforening.dk/object.php?obj = b7d0029 (accessed 1 July, 2007).

Klastrup, L. (2007), "Digital formidling til børn i det sociale nets tidsalder - med Kulturjagt.dk som eksempel", in Hansen, J. and Hansen, C. (Eds), Digital Kulturformidling - børn og forskere har ordet, Kulturarvstyrelsen, Copenhagen, pp. 55-66.

Long, E. (2003), Book Clubs. Women and the Use of Reading in Everyday Life, University of Chicago Press, Chicago, IL.

Lund, N.D. (2006), "Skønlitterære læsekredse - mellem livsverden, marked og folkebibliotek", in Rasmussen, E. and Skot-Hansen, A. (Eds), Folkebiblioteket som forvandlingsrum. Perspektiver $i$ kultur - og medielandskabet, Danmarks Biblioteksforening \& Danmarks Biblioteksskole, Copenhagen, pp. 105-18 (in Danish).

McGarthy, C., Yzerbyt, V.Y. and Spears, R. (2002), Stereotypes as Explanations:The Formation of Meaningful Beliefs about Social Groups, Cambridge University Press, Cambridge.

Radford, G.P. and Radford, M.L. (2003), "Librarians and party girls: cultural studies and the meaning of the librarian”, Library Quarterly, Vol. 73 No. 1, pp. 54-69.

van Riel, R. and Thomas, H. (2007), "Opening the book project", available at: www. openingthebook.com (accessed 1 July, 2007).

Wiegand, W. (1999), "Tunnel vision and blind spots: what the past tells us about the present reflections on the twentieth-century history of American librarianship", Library Quarterly, Vol. 69 No. 1, pp. 1-32.

\section{Digital reading} groups

63 
NLW

$109,1 / 2$

64

\section{Further reading}

Herring, S.C., Scheidt, L.A., Bonus, S. and Wright, E. (2004), Bridging the Gap: A Genre Analysis of Weblogs, available at: www.ics.uci.edu/ jpd/classes/ics234cw04/herring.pdf (accessed 2 July, 2007).

Jochumsen, H. and Rasmussen, C.H. (2006), Folkebiblioteket under forandring. Modernitet, felt og diskurs, Danmarks Biblioteksforening \& Danmarks Biblioteksskole, Copenhagen (in Danish).

Radford, G.P. and Radford, M.L. (2001), "Libraries, librarians and the discourse of fear”, Library Quarterly, Vol. 71 No. 3, pp. 299-329.

Schreiber, T. (2006), "Bibliotekarprofessionen siden 1960'erne”, in Elbeshausen, H. and Schreiber, T. (Eds), Bibliotekarerne - en profession i et felt af viden, kommunikation og teknologi, Vol. 15-47, Samfundslitteratur, Copenhagen, pp. 15-47.

Skouvig, L. (2004), "De danske folkebiblioteker 1880-1920: en kulturhistorisk undersøgelse ud fra dannelses- og mentalitetshistoriske aspekter", available at: http://biblis.db.dk/uhtbin/ hyperion.exe/db.lausko04 (in Danish).

\section{About the authors}

Gitte Balling is based at the Royal School of Library and Information Science, Copenhagen, Denmark. She can be contacted at: gb@db.dk

Lise Alsted Henrichsen is based at the Royal School of Library and Information Science, Copenhagen, Denmark. She can be contacted at: lah@db.dk

Laura Skouvig is based at the Royal School of Library and Information Science, Copenhagen, Denmark. She can be contacted at: 1s@db.dk 